Research.

\title{
THE INFLUENCE OF THE LIFE CYCLE ON THE EFFICIENCY OF THE COMPANY'S INVESTMENT IN THE FOOD AND BEVERAGE SECTOR IN INDONESIA
}

\author{
Nabila Maharani ${ }^{1^{*}}$; Elga Adestria ${ }^{2)}$; Raihan Fadhillah Aqshal ${ }^{3)}$ \\ Farah Margaretha Leon ${ }^{4)}$ \\ Trisakti University, Jakarta \\ nabila022001801129@std.trisakti.ac.id ${ }^{* 1}$; elga022001800057@std.trisakti.ac.id2); \\ raihan022001801033@std.trisakti.ac.id ${ }^{3)}$; farahmargaretha@trisakti.ac.id ${ }^{4)}$ \\ * Corresponding author
}

Received: July 2, 2021 Accepted: August 12, 2021 Published: December 30, 2021

To cite this article: Maharani, N; Adestria, E; Aqshal, RF; Leon, FM. (2021). The Influence of The Life Cycle on The Efficiency of The Company's Investment In The Food and Beverage Sector in Indonesia. The Management Journal Of Binaniaga, 6 (2), 103-116 . doi: 10.33062/mib.v6i2.445

Abstract. This research examines the role of the Company Life Cycle stage in determining investment efficiency of 36 food and beverage companies listed on the Indonesia Stock Exchange for 4 years (2016-2019). And using multiple linear regression analysis method. The independent variable in this research is the Company Life Cycle, while the dependent variable is the company's investment efficiency. There are 3 control variables in this research, namely leverage, firm size, and cash flow. The results of this research indicate that the Company Life Cycle (Intro, Growth, Mature, and Decline) specifically Intro and Decline have no significant effect on Investment Efficiency 1, while Growth and Mature have a negative or significant effect on Investment efficiency 1 . The results of this research can be useful for managers, policy makers, and investors. For Managers, this research encourages managers to adjust investment policies to the stages of the life cycle of each company. For policy makers, they will be able to optimize what policies should be implemented, while for investors, they will be wiser in making decisions in the efficiency of their investment portfolios.

Keywords: company life cycle; investment efficiency; food and beverage companies; Indonesia

\section{INTRODUCTION}

The growth and development of the industry in the food and beverage sector is currently advancing rapidly in the economy and an increase in consumer demand for a product to meet needs. Indonesia has a very large population, so it has an impact on the large increase in the amount of public consumption. Judging from this number, it will certainly make Indonesia a potential target market and an investment target for investors. One of them is the food and beverage sector, this sector is considered to be a sector that is expected to be able to grow and withstand the crisis. The food and beverage sector be one of the manufacturing sectors that makes a major contribution to economic growth (https://kemenperin.go.id/). The Ministry of Industry noted, throughout 2018, the food and beverage industry been able to grow by $7.91 \%$, and became one of the sectors that increased the value of national investment in 2018.

Nabila Maharani; Elga Adestria; Raihan Fadhillah Aqshal; Farah Margaretha Leon. The Influence of The Life Cycle on The Efficiency of The Company's Investment In The Food and Beverage Sector in Indonesia 
All industries will inevitably go through various stages or cycles, namely the cycle of introduction, growth, maturity, and decline. Changes in the very fast economic cycle will cause more cases in business, both in terms of financial and non-financial. Basically, the company is not only a matter of being able to adapt to the situation, but also being able to maintain the sustainability of the company and maximize company profits and the prosperity of the company owners. However, to be able to get maximum profit, the company must be able to allocate and add value to the company. Therefore, company managers must allocate funds efficiently, it will improve company performance and investment efficiency is reflected in sustainable financial performance (Ahmed et al., 2021). If the company manager is able to do this, it will make investors tend to invest excess funds.

The Company Life Cycle can be seen from various aspects such as the age of the company and the size of the company, but the Company Life Cycle which is assessed by the age of the company and the size of the company is very inflexible and not suitable to be used to describe the diversity of each company because the company is considered to be going through the stage of introduction. until it declines sequentially and dies. Previous research mentioned that the theoretical literature proposes a threestage, four-stage, or five-stage model that focuses primarily on the description of the product life cycle, while viewing the company as an aggregation of a single product cycle. Overall, most of the models agree about the stages of introduction, growth, and maturity. In addition, the high-level model also includes the post-maturation stage. From an empirical perspective, current research does not have a consensus on how to further identify each stage of the life cycle. Empirical implementation in financial research, so far, has been dominated by the univariate approach to mapping the company life cycle. However, the implicit assumption when using these measures is that the company moves monotonously from intro to maturity, until it enters the final "decline" stage (Drobetz et al., 2015).

In this research, the life cycle is classified from a combination of operating cash flows, investment cash flows, and financing cash flows. Research on the relationship between the Company Life Cycle and investment efficiency has been carried out previously. Previous research has explained whether the Company Life Cycle affects the efficiency of investment in companies in various sectors in Pakistan (Ahmed et al., 2021). Meanwhile, this research focuses on the relationship between investment efficiency and the Company Life Cycle, especially in the consumer goods sector in Indonesia.

\section{Theoretical basis Company Life Cycle}

The concept of company life cycle management is considered capable of increasing production and service, this is the main key that leads to sustainable company performance. Companies have a cycle that is almost the same as humans, at first the company will build, then grow, mature and then one day will die. The Company Life Cycle also has several stages resulting from internal and external impacts, such as the competitive environment, resources, managerial capabilities to the strategies used by the company. The Company Life Cycle is quite influential on the company's performance. In previous research, it was stated that the company's investment, financing, and cash policy are interrelated and change in line with their life cycle (Faff et al., 2016).

The company life cycle is divided into stages where in the early stages of the Company Life Cycle will greatly affect their ability to compete in a particular industry. The second stage of the Company Life Cycle is known as the growth stage, where the company starts to expand their production and sales, so that their cash inflows become higher. During the growth stage the company will enjoy high profitability and have a more structured operating system. Previous research, it was stated that at this stage, when

Nabila Maharani; Elga Adestria; Raihan Fadhillah Aqshal; Farah Margaretha Leon. The Influence of The Life Cycle on The Efficiency of The Company's Investment In The Food and Beverage Sector in Indonesia 
compared to companies in the intro stage, they are considered more structured in the company's operations and have decentralized decision making, also sales volume and market share increase substantially and debt ratios begin to decline (Drobetz et al., 2015; Heikal et al., 2014). The third stage of the Company Life Cycle, namely the mature stage, the company at this stage will have or face lower cash flow risk, experience higher income and return on assets. Next, investors will analyze the company at a mature stage because it will be considered capable of creating more stable profits. The last stage is the decline stage, at this stage the company must have product innovations to avoid falling prices which result in a decrease in profits. This is associated with the characteristic of the decline stage, namely with an increase in the number of production units but the company is unable to attract new customers. (Ahmed et al., 2021) Companies at this stage will have or face lower cash flow risk, experience higher income and return on assets. Next, investors will analyze the company at a mature stage because it will be considered capable of creating more stable profits. The last stage is the decline stage, at this stage the company must have product innovations to avoid falling prices which result in a decrease in profits. This is associated with the characteristic of the decline stage, namely with an increase in the number of production units but the company is unable to attract new customers. (Ahmed et al., 2021) Companies at this stage will have or face lower cash flow risk, experience higher income and return on assets. Next, investors will analyze the company at a mature stage because it will be considered capable of creating more stable profits. The last stage is the decline stage, at this stage the company must have product innovations to avoid falling prices which result in a decrease in profits. This is associated with the characteristic of the decline stage, namely with an increase in the number of production units but the company is unable to attract new customers. (Ahmed et al., 2021) Next, investors will analyze the company at a mature stage because it will be considered capable of creating more stable profits. The last stage is the decline stage, at this stage the company must have product innovations to avoid falling prices which result in a decrease in profits. This is associated with the characteristic of the decline stage, namely with an increase in the number of production units but the company is unable to attract new customers. (Ahmed et al., 2021) Next, investors will analyze the company at a mature stage because it will be considered capable of creating more stable profits. The last stage is the decline stage, at this stage the company must have product innovations to avoid falling prices which result in a decrease in profits. This is associated with the characteristic of the decline stage, namely with an increase in the number of production units but the company is unable to attract new customers. (Ahmed et al., 2021)

\section{Investment Efficiency}

Investment is one of the capital projects carried out by the company to obtain greater capital opportunities so as to maximize profits and add value to the company. In its activities, managers must have the power to manage funding sources efficiently, with an efficient level of allocation of funds, the company's performance will increase which then has an impact on financial performance which increases the value of the company. Previous studies suggest that managers rarely distribute their resources efficiently (Cheng et al., 2013). Managers tend to invest more or less at a certain time which ends in a decrease in the company's investment efficiency.

\section{Leverage, Firm Size, Cash Flow}

Control variables are also needed in the measurement in this article, namely there are several variables including Leverage, Firm Size, Cash Flow. Leverage is used for debt funds or loans to enlarge the business, such as increasing the production of Tobin's $Q$ in general, being one of the measuring tools or ratios that explain the value of the company. These four variables are needed in measuring the effect of the company's cycle on the company's investment efficiency. Research conducted by Hamidah \&

Nabila Maharani; Elga Adestria; Raihan Fadhillah Aqshal; Farah Margaretha Leon. The Influence of The Life Cycle on The Efficiency of The Company's Investment In The Food and Beverage Sector in Indonesia 
Umdiana (2017), Suffah \& Riduwan (2016), \& Analysis (2011) which says that profitability has a positive effect on firm value. The size of the company in this research is a reflection of the size of the company that appears in the total value of the company's assets. This affects investors expect dividends from the company. The increasing demand for company shares will be able to spur an increase in share prices in the capital market. The increase indicates that the company is considered to have greater "value". (Hirdinist, 2019)

\section{Conceptual Framework}

Investment efficiency is one that is considered important for the company and makes a benchmark in assessing a company's performance. Based on this explanation, the conceptual framework in this research can be described as follows:

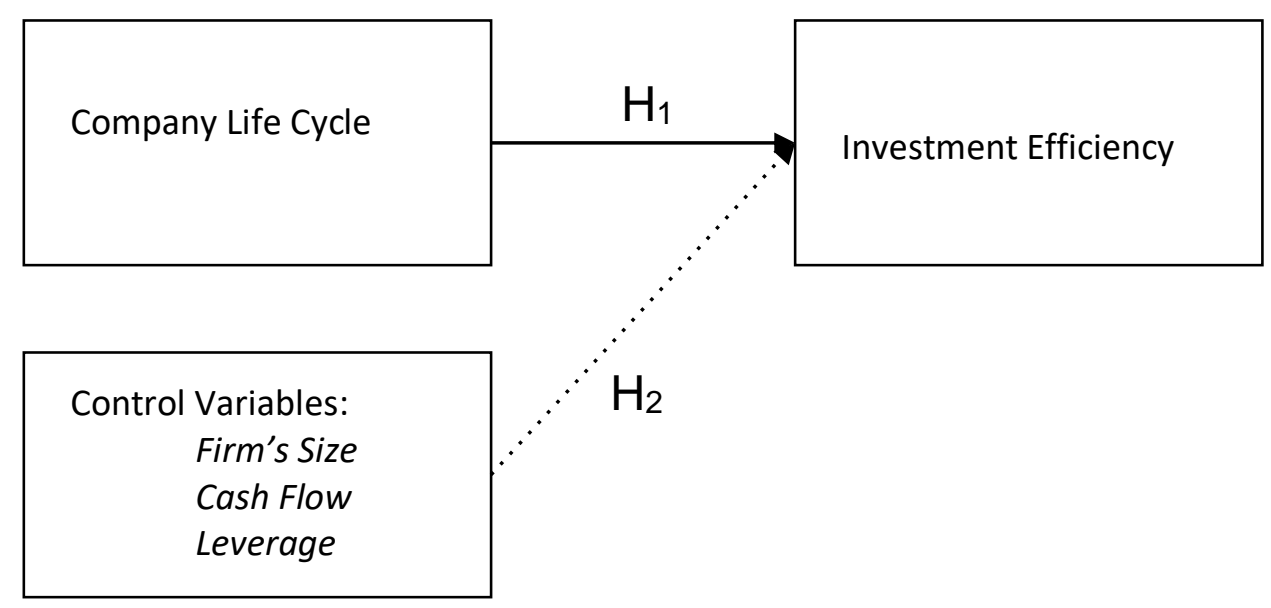

Figure 1

Conceptual Framework Section

The Effect of the Company Cycle on Investment Efficiency

In the Food and Beverage Sector in Indonesia

\section{Hypothesis Development}

The company's investment efficiency is usually one of the benchmarks for the value of a company. Investment efficiency is seen from how company managers are able to allocate existing resources according to company needs. Previous studies measure investment efficiency using the ROI ratio where the ratio is divided into three types, namely INE 1, INE 2, and INE 3 (Ahmed et al., 2021). The company life cycle itself is divided into four parts, namely, introduction, growth, maturity and decline.

Habib and Hasan stated that companies that are in the decline stage will face many challenges, both internal and external. This will have an impact on investors' image of the company and reduce existing investment (Habib \& Hasan, 2019). Previous research has also confirmed that investment risk also increases as a company enters the decline stage (Habib \& Hasan, 2017). Based on the discussion, the first hypothesis (H1) can be formulated as follows:

\section{$\mathrm{H}_{1}$ : There is an influence between the company life cycle on the company investment efficiency.}

Nabila Maharani; Elga Adestria; Raihan Fadhillah Aqshal; Farah Margaretha Leon. The Influence of The Life Cycle on The Efficiency of The Company's Investment In The Food and 
Control variables are also needed in the measurement in this article, namely there are several variables including Leverage, Cash Flow, Firm Size. Firm size, Cash flow, Leverage are expected to have a positive influence on the company's investment efficiency. Based on the description; then the hypothesis $\mathrm{H} 2$ can be proposed as follows:

\section{$\mathrm{H}_{2}$ : There is an effect of control variables consisting of Firm Size, Cash Flow, and Leverage on the company's investment efficiency. RESEARCH METHOD}

\section{Variables and Variable Measurement}

The company cycle becomes something that is considered to affect the company's investment efficiency. So, this research has examined variables including dependent variables, independent variables, and control variables. The dependent variable is Investment Efficiency. The independent variable is the Company Cycle. As for the control variable, there are 3 control variables, namely Leverage, Firm Size, and Cash Flow. Each variable has a measurement for the research:

Table 1

Variable Identification and Measurement

\section{Sampling Method}

\begin{tabular}{|c|c|c|c|c|}
\hline Variables & Proxy & $\underset{s}{S y m b o l}$ & Measurements & References \\
\hline $\begin{array}{l}\text { Investment } \\
\text { Efficiency }\end{array}$ & $\begin{array}{l}\text { Investment } \\
\text { Efficiency } \\
\text { (ROI) }\end{array}$ & INE & $\begin{array}{l}\text { Total Sales-Total Expense/Total } \\
\text { Expense }\end{array}$ & (Jiang \& Akbar, 2018) \\
\hline \multirow{4}{*}{$\begin{array}{l}\text { Company Life } \\
\text { Cycle }\end{array}$} & Introduction & Intro & $O P C F<0, I N C F<0$ and $F C F>0$ & (Dickinson, V. 2011) \\
\hline & Growth & Growth & $O P C F>0, I N C F<0$ and $F C F>0$ & (Dickinson, V. 2011) \\
\hline & Mature & Mature & $O P C F>0, I N C F<0$ and $F C F<0$ & (Dickinson, V. 2011) \\
\hline & Decline & Decline & $\begin{array}{l}O P C F<0, I N C F>0 \text { and } F C F_{-} \text {or } \\
0 ;\end{array}$ & (Dickinson, V. 2011) \\
\hline \multirow{3}{*}{$\begin{array}{l}\text { Variable } \\
\text { Control }\end{array}$} & Firm size & Size & Natural log of total asset at year $t$. & (Hasan et al., 2020) \\
\hline & Cash Flows & CF & $\begin{array}{l}\text { Net Cash flow from operation/Total } \\
\text { Asset }\end{array}$ & (Noor et al., 2012) \\
\hline & LEVG & LEV & Total liabilities/stake-holders equity & (DERMADI, 2017) \\
\hline
\end{tabular}

Nabila Maharani; Elga Adestria; Raihan Fadhillah Aqshal; Farah Margaretha Leon. The Influence of The Life Cycle on The Efficiency of The Company's Investment In The Food and Beverage Sector in Indonesia 
The data collection method used is to collect secondary data, meaning that this research takes research data indirectly. Data can be taken from previously published sources. The research data is taken from the IDN finance website (https://www.idnfinancials.com/). The data of this research consist of Food and Beverage companies listed on the Indonesia Stock Exchange (IDX). The population for Food and Beverage companies on the IDX consists of 36 companies and only 20 companies are considered eligible to be sampled, with the following considerations:

Table 2

Sampling Criteria

\begin{tabular}{|l|c|}
\hline \multicolumn{1}{|c|}{ Remarks } & $\begin{array}{c}\text { Number of } \\
\text { Companies }\end{array}$ \\
\hline $\begin{array}{l}\text { Food and Beverage sector companies listed on the Indonesia Stock Exchange for } \\
\text { the 2016-2019 Period }\end{array}$ & 36 \\
\hline Companies whose data are incomplete in the financial statements & 16 \\
\hline Number of companies eligible to be sampled & 20 \\
\hline
\end{tabular}

\section{Research Regression Model}

The model to test the relationship between the variables of this research uses the following regression model:

$$
I E_{i t}=a_{0}+\Sigma_{i=1}^{4} \beta_{i} F L C_{i, t}+\beta_{5} T Q_{i t}+\beta_{6} \text { size }_{i t}+\beta_{7} L E V G_{i t}+\beta_{8} C F_{i t}+\varepsilon_{i}
$$

Keterangan:

$I E_{\text {it }} \quad=$ Investment efficiency

FLCS $_{i, t}=$ vector of dummy variables that represent life cycle stages (intro, growth, maturity, dan decline)

$T Q_{i t} \quad=$ value of Tobin's $Q$

size $_{\text {it }}=$ logarithm of total asset

$L E V G_{i t}=$ firm leverage ratio

$C F_{i t} \quad=$ cash flow of the firm

There are several stages of testing the regression model used in this research, namely:

\section{Hausman Test}

The results of the Hausman Test are used to see whether fixed effects or random effects are the best method. The hypothesis in the Hausman test is stated as follows:

$\mathrm{H}_{0}$ : Model Following random effects

$\mathrm{H}_{1}$ : Model Following fixed effects

Nabila Maharani; Elga Adestria; Raihan Fadhillah Aqshal; Farah Margaretha Leon. The Influence of The Life Cycle on The Efficiency of The Company's Investment In The Food and Beverage Sector in Indonesia 
The decision criteria are as follows:

a. If the statistical cross-section probability $>0.05$, then $\mathrm{HO}$ is accepted

b. If the statistical cross-section probability $<0.05$, then $\mathrm{H} 0$ is rejected

According to the table of the results of the Hausman test (table 3), the results of model 1 show that the probability value of cross-section statistics is $0.3887>0.05$, so the decision that can be obtained is $\mathrm{HO}$ is accepted so that the model used is the Random effect model.

According to the table of test results Hausman test, the results of model 2 shows that the probability of a cross-section Statistic of $0.6515>0.05$, then the decision can be obtained by $\mathrm{HO}$ is accepted that the model used is the random effect model

According to the table of test results Hausman test, the results of model 3 show that the probability value of cross-section Statistics is $0.2854>0.05$, then the decision that can be obtained is $\mathrm{HO}$ is accepted so that the model used is the Random effect model.

$\begin{array}{ll}\text { Dependent Variable } & : \text { INE } \\ \text { Chi-square } & : 3.019339 \\ \text { Probability } & : 0.3887 \\ \text { Decision } & : \text { Accepted } \mathrm{H}_{0}, \text { Random Effect is selected } \\ \text { Source } & : \text { Data is processed using E-Views }\end{array}$

\section{Lagrange Multiplier Test Results}

The results of the lagrange multiplier are used to determine whether the right model is between random effects or common effects. This test was developed by Breusch Pagan. The hypothesis in the Lagrange multiplier test is stated as follows:

$\mathrm{H}_{0}$ : The right model is the common effect

$\mathrm{H}_{1}$ : The right model is the random effect

As for the decision criteria, it is stated as follows:

a. If the cross-section probability of Breusch-Pagan $<0.05 \mathrm{H}_{0}$ rejeceted

b. If the cross-section probability of Breusch-Pagan $>0.05 \mathrm{H}_{0}$ accepted

According to the table of LM Test results, the results of model 1 and model 2 show that the probability value of the cross-section statistic is $0.0000<0.05$, so the decision that can be obtained is $\mathrm{H}_{0}$ is rejected so that the model used is the Random effect model.

According to the table of LM Test results, the results of model 3 show that the probability value of cross-section statistics is $0.0496<0.05$, so the decision that can be obtained is $\mathrm{H}_{0}$ is rejected so that the model used is the Random effect model.

$\begin{array}{ll}\text { Dependent Variable } & : \text { INE } \\ \text { Chi-square } & : 101.2850 \\ \text { Probability } & : 0.0000 \\ \text { Decision } & : \text { Rejected } \mathrm{H}_{0}, \text { Random Effect selected } \\ \text { Source } & : \text { Data is processed using E-Views }\end{array}$

Nabila Maharani; Elga Adestria; Raihan Fadhillah Aqshal; Farah Margaretha Leon. The Influence of The Life Cycle on The Efficiency of The Company's Investment In The Food and Beverage Sector in Indonesia 


\section{Descriptive Statistical Analysis}

\section{Data Analysis Method}

This descriptive statistical analysis is used to provide an overview of the data in this research. This analysis addresses statistical measures such as center size, dispersion measure, and size within the data distribution. This analysis aims to summarize the data so that it can provide an overview and information that will be easily understood because the data exposure becomes clearer and more detailed. This analysis is done by calculating the variation of the mean (mean), median, and also the standard deviation of each variable, Efficiency Investment (dependent variable); Company life cycle (independent variable); and firm's size, Cash Flow, Leverage (control variable).

\section{F Test}

This $\mathrm{F}$ test is used to test whether the independent variable (Company Life Cycle) and control variable (cash flow, Firm's size, and leverage) affect the dependent variable (Efficiency Investment) simultaneously. This $F$ test aims to assess whether the model used is feasible or not. This test has the following hypotheses:

$\mathrm{H}_{0}$ : The independent variables simultaneously have no significant effect on the dependent variable, so the model is not feasible to use

$\mathrm{H}_{1}$ : The independent variables simultaneously have significant effect on the dependent variable, so the model is feasible to use

The criteria for decision making are stated as follows:

a. If the probability of $\mathrm{F}$-statistic $<0.05, \mathrm{H}_{0}$ rejected

b. If the probability of F-statistic $>0.05, \mathrm{H}_{0}$ accepted

\section{Goodness of Fit Test $\left(\mathbf{R}^{2}\right)$}

The Goodness of Fit test is used to test how much influence the independent and control variables have with the dependent variable. This test is performed using the value of the adjusted $r$-square. If the adjusted $r$-square value is close to 1 , it can be interpreted that the independent variable is able to affect the dependent variable. The criteria and decision making are:

a. The adjusted r-square value is close to 1 , so the influence of the independent variable in explaining the dependent variable is getting higher.

b. The adjusted $r$-square value is close to 0 , so the influence of the independent variable in explaining the dependent variable is getting lower.

\section{T Test}

T test is used to test how the effect of each independent variable and control variable partially on the dependent variable. This test has the following hypotheses:

$\mathrm{H}_{0}$ : There is no influence between the independent variable and the control variable on the dependent variable

$\mathrm{H}_{1}$ : There is influence between the independent variable and the control variable on the dependent variable

Nabila Maharani; Elga Adestria; Raihan Fadhillah Aqshal; Farah Margaretha Leon. The Influence of The Life Cycle on The Efficiency of The Company's Investment In The Food and Beverage Sector in Indonesia 
The criteria for decision making are stated as follows:

a. If the probability of $\mathrm{T}<0.05, \mathrm{H}_{0}$ rejected

b. If the probability of $\mathrm{T}>0,05, \mathrm{H}_{0}$ accepted

\section{RESULTS AND DISCUSSION}

\section{Descriptive Statistical Analysis}

According to the Table 3 Descriptive Statistical Analysis Test, there are interpretations which are explained as follows:

The INE model has an average value of 4.739149 and has a standard deviation of 3.312226 . The maximum value of INE1 is 16,539 which is owned by PT Buyung Poetra Sembada Tbk in 2018 and the minimum value of INE1 is -0.673 which is owned by PT FKS Food Sejahtera Tbk in 2017.

Firm' Size (SIZE) has an average value of 11,76658 and standard deviation of 1.852733. The maximum value for SIZE is 13,994 which is owned by PT Indofood Sukses Makmur in 2018 and the minimum value of SIZE is 5,915 which is owned by PT Akasha Wira International Tbk in 2019.

Cash Flow (CF) has an average value of 0.07450 and a standard deviation of 0.1178 . As for the maximum value of CF of 0.501 which is owned by PT FKS Food Sejahtera Tbk in 2016 and the minimum value of CF is -0.311 which is owned by PT. Prima Cakrawala Abadi Tbk. in 2018.

Leverage (LEVG) has an average value of 0.695541 and a standard deviation of 0.891395 . As for the maximum value on the LEVG of 3.338925 which is owned by PT. Prasidha Aneka Niaga Tbk. in 2019 and the minimum value of LEVG is -3.021300 which is owned by T. Prima Cakrawala Abadi Tbk. in 2016.

Table 3

Descriptive Statistical Analysis Results

\begin{tabular}{|c|c|c|c|c|c|c|c|}
\hline & INE & INTRO & GROWTH & MATURE & SIZE & CF & LEVG \\
\hline Mean & 4.739149 & 0.150000 & 0.300000 & 0.500000 & 11.76658 & 0.079450 & 0.695541 \\
\hline Max & 16.53900 & 1.000000 & 1.000000 & 1.000000 & 13.99400 & 0.501000 & 3.338925 \\
\hline Min & -0.673000 & 0.000000 & 0.000000 & 0.000000 & 5.915000 & -0.311000 & -3.021300 \\
\hline Std. Dev & 3.312226 & 0.359324 & 0.461149 & 0.503155 & 1.852733 & 0.117800 & 0.891395 \\
\hline
\end{tabular}

\section{F Test Result}

According to the results of the $\mathrm{F}$ test in model 1 , it can be seen that the probability F-statistic produces a value of $0.016123<0.05$. Thus, the results of the analysis in this research indicate that together the independent variables namely intro, growth, mature, cash flow, firm size and leverage have an influence on investment efficiency, so that the regression model is feasible to use in this research.

$\begin{array}{ll}\text { Dependent Variable } & : \text { INE } \\ \text { F-statistic } & : 2.813562 \\ \text { Probability } & : 0.016123\end{array}$

Nabila Maharani; Elga Adestria; Raihan Fadhillah Aqshal; Farah Margaretha Leon. The Influence of The Life Cycle on The Efficiency of The Company's Investment In The Food and Beverage Sector in Indonesia 
The Management Journal of BINANIAGA Vol. 06, No.02, December 2021

p-ISSN: 2527 - 4317, e-ISSN: $2580-149 x$

$6^{\text {th }}$ Accreditation Rating: April 04, $2019-$ April 03, 2024

$\begin{array}{ll}\text { Decision } & : \text { Rejected } \mathrm{H}_{0} \\ \text { Source } & : \text { Data is processed using E-Views }\end{array}$

\section{Goodness of Fit Test Result}

According to the results of the goodness of fit test in model 1, the adjusted r-square value is 0.121064 . This means that the independent variables, namely intro, growth, mature, cash flow, firm size and leverage are able to explain variations from investment efficiency 1 of $12,1064 \%$ and the remaining $87,8936 \%$ explaining that investment efficiency 1 can be influenced by other factors not included in this model. There is a weak relationship between intro, growth, mature, cash flow, firm size and leverage on investment efficiency.

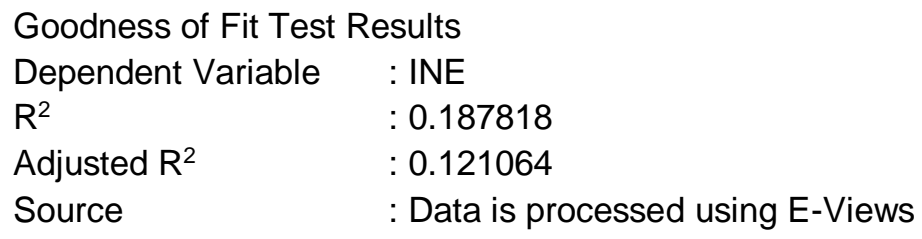

\section{Regression T Test Result}

Table 4

Regression T Test

\begin{tabular}{|c|c|c|c|}
\hline \multirow{2}{*}{$\begin{array}{c}\text { Independent } \\
\text { Variable }\end{array}$} & \multicolumn{3}{|c|}{ Dependent Variable } \\
\cline { 2 - 4 } & Coefficient & Probability & Conclusion \\
\cline { 2 - 4 } & 7.587682 & - & - \\
\hline Constant & 1.556768 & 0.6031 & Not Significant \\
\hline INTRO & -3.585942 & 0.0170 & Negative Significant \\
\hline GROWTH & -2.424480 & 0.0362 & Negative Significant \\
\hline MATURE & -0.139156 & 0.3880 & Not Significant \\
\hline SIZE & 3.937450 & 0.0840 & Not Significant \\
\hline CF & 0.762771 & 0.1126 & Not Significant \\
\hline LEVG &
\end{tabular}

Source: Data is processed using E-Views

1. Introduction (INTRO) has a probability value of $0.6031>0.05$ (alpha $5 \%$ ) which shows an insignificant effect. The results of this research conclude that there is no significant effect between Introduction on investment efficiency.

2. Growth (GROWTH) has a probability value of $0.0170<0.05$ (alpha $5 \%$ ) which shows a significant effect. The magnitude of the coefficient is -3.585942 . The results of this research conclude that there is a negative and significant effect between growth on investment efficiency.

3. Mature (MATURE) has a probability value of $0.0362<0.05$ (alpha $5 \%$ ) which shows a significant effect. The magnitude of the coefficient is -2.424480 . The results of this research conclude that there is a negative and significant effect between mature on investment efficiency.

Nabila Maharani; Elga Adestria; Raihan Fadhillah Aqshal; Farah Margaretha Leon. The Influence of The Life Cycle on The Efficiency of The Company's Investment In The Food and Beverage Sector in Indonesia 
4. Firm Size (SIZE) has a probability value of $0.3880>0.05$ (alpha $5 \%$ ) which indicates an insignificant effect. The results of this research conclude that there is no significant effect between Firm Size on investment efficiency.

5. Cash Flow (CF) has a probability value of $0.0840>0.05$ (alpha $5 \%$ ) which shows no significant effect. The results of this research conclude that there is no significant effect of cash flow on investment efficiency.

6. Leverage (LEVRG) has a probability value of $0.1126>0.05$ (alpha $5 \%$ ) which shows no significant effect. The results of this research conclude that there is no significant effect of leverage on investment efficiency.

\section{Discussion}

\section{$H_{1}$ : There is an influence between the company life cycle on the company investment efficiency.}

After statistical testing, it can be seen that the value of sig. from each Company Life Cycle is $0.6031>0.05$ ( $\alpha$ ) with a coefficient of 1.556768 for the INTRO section, $0.0170<0.05(\alpha)$ with a coefficient of -3.585942 for the GROWTH section, and $0.0362<$ $0.05(\alpha)$ with a coefficient of -2.424480 for the MATURE section. Thus, each Company Life Cycle has a different effect, for INTRO rejected has a sig result of more than 0.05 which means $\mathrm{HO}$ is accepted and $\mathrm{Ha}$, INTRO has an insignificant effect on investment efficiency. Meanwhile, GROWTH and MATURE have a value that is less than the alpha value with a negative coefficient, meaning that $\mathrm{H}_{0}$ is rejected and $\mathrm{Ha}$ is accepted, where at the GROWTH and MATURE stages it has a significant negative effect on investment efficiency. This is in line with research conducted by (Ahmed et al., 2021) which states that when a company is at the INTRO stage, it will face higher financial costs, a higher risk of bankruptcy (Akbar et al., 2019), a lower production process. inefficient, negative returns, and inability to attract new customers. Thus, any investment made during the INTRO stage will develop in a lower direction. When compared to the GROWTH and MATURE stages, it produces positive results, has a higher level of profitability, has lower uncertainty related to cash flow. Therefore, the investment made at this stage will result in increased sales and ultimately increase the efficiency of the resources used.

\section{$\mathrm{H}_{2} \quad$ : There is an effect of control variables consisting of Firm Size, Cash Flow, and Leverage on the company investment efficiency.}

In testing the control variable, the test results on Firm's Size show the value of sig. of $0.3880>0.05(\alpha)$ with a coefficient of -0.139156 , it can be concluded that $\mathrm{HO}$ is accepted and $\mathrm{Ha}$ is rejected. Firm's size has no significant effect on the company's investment efficiency. In this research, the size of the company does not show a significant impact on the efficiency of investing, because in general there is no guarantee of how much the company can guarantee its financial effectiveness. The main indicator is the company's financial health which definitely has an impact on investment efficiency. And ofcourse this efficiency may be found in large or small companies depending on how their finances are managed.

The test results on the Cash Flow control variable have a sig value of $0.0840>$ 0.05 ( $\alpha$ ) with a coefficient of 3.937450 , it can be concluded that $\mathrm{HO}$ is accepted and $\mathrm{Ha}$ is

Nabila Maharani; Elga Adestria; Raihan Fadhillah Aqshal; Farah Margaretha Leon. The Influence of The Life Cycle on The Efficiency of The Company's Investment In The Food and Beverage Sector in Indonesia 
rejected. Cash Flow has no significant effect on the company's investment efficiency. Cash flow is not a benchmark for investment efficiency, because if it is oriented to cash outflow, the more funds that come out, be it operational, funding, and investment, do not reflect the company is experiencing losses or financially unhealthy. There is the opposite possibility, where the outgoing funds can provide returns in the future period, considering that not all expenditures are consumptive, but can be productive.

The test results on the last control variable, namely Leverage, have a sig value. of $0.1126>0.05$ ( $\alpha$ ) with a coefficient of 0.762771 , it can be concluded that $\mathrm{H} 0$ is accepted and $\mathrm{Ha}$ is rejected. Leverage has no significant effect on the company's investment efficiency.

In a previous research, it was stated that the investment efficiency of the company was lower at the intro stage (Ahmed et al., 2021). Meanwhile, for this research, it can be proven that there is a negative and significant influence between growth and maturity on investment efficiency.

\section{CONCLUSSION}

Based on the results of the tests carried out, there are several conclusions, namely:

- Company Life Cycle variables (Intro, Growth, Mature, Decline) have no significant effect on investment efficiency.

- Company Life Cycle variable as measured by Intro, Growth, Mature, Decline. Specifically, Intro and Decline have no significant effect on Investment Efficiency 2 and 3 , while Growth and Mature have a negative or significant effect on Investment Efficiency 1.

- Control variables such as firm's size, Cash Flow, and Leverage have no significant effect on investment efficiency.

\section{IMPLICATION}

According to the results of this research, there are benefits that can be taken as implications for financial managers to be taken into consideration by companies in carrying out policies and considerations for further research. Some of these implications are as follows:

\section{A. For Managers}

For Managers, this research encourages managers to adjust investment policies to the life cycle stages of each company, because each company has different life cycle stages, conditions, and investment priorities. On the other hand, as it is known that every company goes through 4 stages, namely introduction, growth, maturity, and decline. In accordance with the tests that have been carried out, it can be seen from these measurements that the efficiency of the investment made by the company experiences the smallest coefficient or minus at the intro and growth stages, so based on these results it can be concluded that the management must take advantage of existing sources of funds in terms of investment when it is at the investment stage. the. Because especially at this stage the tendency of the company's income statement is in a fairly good condition, obtained sales and income from operational and investment activities. So, it can be emphasized that this phase is very good for managers to

Nabila Maharani; Elga Adestria; Raihan Fadhillah Aqshal; Farah Margaretha Leon. The Influence of The Life Cycle on The Efficiency of The Company's Investment In The Food and Beverage Sector in Indonesia 
expand their business in terms of making decisions related to financial decisions. On the other hand, management can optimize the company's financial capabilities when it is in the growth and maturity stages, because the two variables in the test produce large or positive coefficients. Given that investment efficiency tends to be low at certain stages, investors need to prepare themselves proactively and make better decisions to improve the efficiency of their investment portfolios, as well as to avoid the risk of a decline in the company's financial health. So, it can be emphasized that this phase is very good for managers to expand their business in terms of making decisions related to financial decisions.

\section{B. For Investors}

For Investors, it is better to invest in food and beverage companies in particular. In fundamental analysis, it is recommended to review and analyze financial statements, especially the company's income statement, so that investors are able to estimate which company they want to invest in is currently at what stage of its life cycle. Based on the research that has been done, it is recommended to invest in companies that are in the Growth and Mature stages so that investors can minimize the risk of loss and maximize the best return.

\section{LIMITATIONS AND SUGGESTIONS}

According to the results of the research conducted, this research has several limitations, including the following: This research only examines companies engaged in the Food and Beverages industry in Indonesia, especially the IDX (Indonesian Stock Exchange) where companies in one sector still have incomplete data. in the company's annual report so that less information is obtained. Also, the limitations of companies in one sector are still too few when compared to previous studies that combined several company sectors.

The current research identifies several interesting areas that Company Life Cycle (FLC) experts could explore in future research. First, most research on FLC is skewed by its implications; therefore, experts should include the company's specific characteristics that affect the company's transition between different stages of the life cycle. The next research opportunity lies in examining the effect of the FLC stages on its performance in the stock market, namely how investors value a company at a certain stage of its life cycle.

\section{REFERENCES}

Ahmed, B., Akbar, M., Sabahat, T., Ali, S., Hussain, A., Akbar, A., \& Hongming, X. (2021). Does firm life cycle impact corporate investment efficiency? Sustainability (Switzerland). https://doi.org/10.3390/su13010197

Akbar, A., Akbar, M., Tang, W., \& Qureshi, M. A. (2019). Is bankruptcy risk tied to corporate life-cycle? Evidence from Pakistan. Sustainability (Switzerland). https://doi.org/10.3390/su11030678

Cheng, M., Dhaliwal, D., \& Zhang, Y. (2013). Does investment efficiency improve after the disclosure of material weaknesses in internal control over financial reporting? Journal of Accounting and Economics, 56(1), 1-18. https://doi.org/10.1016/j.jacceco.2013.03.001

Nabila Maharani; Elga Adestria; Raihan Fadhillah Aqshal; Farah Margaretha Leon. The Influence of The Life Cycle on The Efficiency of The Company's Investment In The Food and Beverage Sector in Indonesia 
The Management Journal of BINANIAGA Vol. 06, No.02, December 2021

p-ISSN: 2527 - 4317, e-ISSN: $2580-149 x$

$6^{\text {th }}$ Accreditation Rating: April 04, $2019-$ April 03, 2024

DERMADI, K. (2017). KONSERVATISME AKUNTANSI ( Studi Empiris Pada Perusahaan Manufaktur yang Terdaftar di Bursa Efek Indonesia Tahun 2013-2015 ). 6, 1-13.

Drobetz, W., Halling, M., \& Schrrder, H. (2015). Corporate Life-Cycle Dynamics of Cash Holdings. SSRN Electronic Journal, 15. https://doi.org/10.2139/ssrn.2578315

Faff, R., Kwok, W. C., Podolski, E. J., \& Wong, G. (2016). Do corporate policies follow a life-cycle? Journal of Banking and Finance, 69(April), 95-107. https://doi.org/10.1016/j.jbankfin.2016.04.009

Habib, A., \& Hasan, M. M. (2017). Managerial ability, investment efficiency and stock price crash risk. Research in International Business and Finance, 42, 262-274. https://doi.org/10.1016/j.ribaf.2017.07.048

Habib, A., \& Hasan, M. M. (2019). Corporate life cycle research in accounting, finance and corporate governance: A survey, and directions for future research. International Review of Financial Analysis, 61, 188-201. https://doi.org/10.1016/j.irfa.2018.12.004

Hasan, M., Rahman, D., Taylor, G., \& Oliver, B. (2020). Crash risk and debt maturity: evidence from Australia. International Journal of Managerial Finance. https://doi.org/10.1108/lJMF-12-2019-0467

Heikal, M., Khaddafi, M., \& Ummah, A. (2014). Influence Analysis of Return on Assets (ROA), Return on Equity (ROE), Net Profit Margin (NPM), Debt To Equity Ratio (DER), and current ratio (CR), Against Corporate Profit Growth In Automotive In Indonesia Stock Exchange. International Journal of Academic Research in Business and Social Sciences, 4(12), 101-114. https://doi.org/10.6007/ijarbss/v4-i12/1331

Hirdinis, M. (2019). Capital structure and firm size on firm value moderated by profitability. International Journal of Economics and Business Administration, 7(1), 174-191. https://doi.org/10.35808/ijeba/204

Jiang, X., \& Akbar, A. (2018). Does increased representation of female executives improve corporate environmental investment? Evidence from China. Sustainability (Switzerland), 10(12). https://doi.org/10.3390/su10124750

Kementerian Perindustrian Republik Indonesia.(n.d)(https://kemenperin.go.id/)

Noor, M. I., Nour, A., Musa, S., \& Zorqan, S. (2012). The Role of Cash Flow in Explaining the Change in Company Liquidity. Journal of Advanced Social Research.

Nabila Maharani; Elga Adestria; Raihan Fadhillah Aqshal; Farah Margaretha Leon. The Influence of The Life Cycle on The Efficiency of The Company's Investment In The Food and Beverage Sector in Indonesia 